\title{
OPTIMALISASI POS UPAYA KESEHATAN KERJA PADA TENAGA KERJA SEKTOR INFORMAL DI WILAYAH KERJA PUSKESMAS WARU, KABUPATEN SIDOARJO
}

\author{
Sho'im Hidayat, dr., MS \\ Prof. Dr. Tri Martiana, dr., M.S \\ Putri Ayuni Alayyannur, S.KM., M.KKK \\ Fakultas Kesehatan Masyarakat, Universitas Airlangga \\ E-mail:putri_a_a@yahoo.com
}

\begin{abstract}
ABSTRAK
Tahun 2011, terdapat 99 industri kecil di Kecamatan Waru yang merupakan wilayah kerja dari Puskesmas Waru. Jumlah tersebut merupakan jumlah terbanyak di Kabupaten Sidoarjo. Hal ini menunjukkan bahwa kelompok industri kecil yang menjadi sasaran program Pos Upaya Kesehatan Kerja (UKK) di wilayah Puskesmas Waru merupakan sasaran yang terbanyak pula di Kabupaten Sidoarjo. Penelitian oleh Wignjosoebroto, Arief dan Dwi tahun 2006 pada salah satu industri metal di daerah Ngingas, Waru, Sidoarjo menunjukkan bahwa terdapat 2 kecelakaan kerja di 2002, 3 kecelakaan kerja di 2003, dan 2 kecelakaan kerja di 2004. Optimalisasi Pos UKK dilakukan dengan beberapa kegiatan yaitu pemberdayaan petugas Puskesmas di Kabupaten Sidoarjo; brainstorming antara petugas dan sektor informal; pemberdayaan tenaga kerja sektor informal; mapping hazard di tempat kerja; dan pembuatan program K3 pada sektor informal. Kegiatan pemberdayaan petugas Puskesmas meliputi workshop yang diikuti oleh seluruh petugas Puskesmas di wilayah kerja Dinas Kesehatan Kabupaten Sidoarjo yang memiliki hak dan tanggung jawab terkait kesehatan dan keselamatan kerja. Brainstorming antara petugas dan sektor informal dilakukan untuk mengidentifikasi masalah yang terjadi dan mendapatkan kesepakatan tindak lanjutnya. Workshop pemberdayaan tenaga kerja sektor informal diberikan materi K3 secara umum, yang disampaikan oleh petugas Puskesmas yang sudah mengikuti workshop di Kabupaten. Mapping hazard di tempat kerja dilakukan untuk memudahkan pengelompokan hazard fisik, kimia, biologi, psikologi, dan ergonomi. Program K3 yang diusulkan pada anggaran daerah yaitu khusus untuk tenaga kerja sektor informal. Sektor informal membutuhkan kehadiran negara dalam mengatasi kesehatan dan keselamatan kerjanya. Pembuatan program K3 ini juga dibarengi dengan pembuatan anggaran dana.
\end{abstract}

Kata kunci: petugas, pos ukk, puskesmas

\section{PENDAHULUAN}

Puskesmas Waru berada di Jl. Barito Pojok No.1 Wisma Tropodo, Waru. Puskesmas Waru berperan melayani kebutuhan layanan kesehatan warga di 11 desa. Dalam catatan Biro Pusat Statistik (BPS) Sidoarjo tahun 2012, ada sekitar 25.733 rumah tangga. Wilayah kerja puskesmas ini didominasi oleh tambak, industri dan pertanian (Puskesmas Waru, 2017).

Sektor industri kecil di Kecamatan Waru pada tahun 2011 dengan jumlah terbanyak di Kabupaten Sidoarjo yaitu dengan jumlah 54 perusahaan dan 99 industri kecil. Hal tersebut menunjukkan bahwa pada tahun 2011, terdapat 99 industri kecil di wilayah Kecamatan Waru yang merupakan wilayah kerja dari Puskesmas Waru. Jumlah tersebut merupakan jumlah terbanyak di Kabupaten Sidoarjo. Hal ini menunjukkan bahwa kelompok industri kecil yang menjadi sasaran program Pos Upaya Kesehatan Kerja (UKK) di wilayah Puskesmas Waru merupakan sasaran yang terbanyak pula di Kabupaten Sidoarjo.

Salah satu desa di wilayah kerja Puskesmas Waru adalah Desa Ngingas. Desa Ngingas, Kecamatan Waru, Kabupaten
Sidoarjo merupakan sentra Industri Kecil dan Menengah (IKM) yang menampung 300 orang pengusaha dan sekitar 3.000 tenaga kerja. Mereka memproduksi barang dari logam seperti spare part kendaraan bermotor, alat pertanian, electrical, dan barang lainnya (Beacukai, 2017).

Kejadian kecelakaan kerja pada tenaga kerja sektor informal di Waru, Sidoarjo sudah lama menjadi perhatian beberapa pihak. Hal ini ditunjukkan dengan adanya penelitian oleh Wignjosoebroto, Arief dan Dwi (2006) pada salah satu industri metal di daerah Ngingas, Waru, Sidoarjo. Pada penelitian tersebut didapatkan data bahwa terdapat 2 kecelakaan kerja di 2002, 3 kecelakaan kerja di 2003, dan 2 kecelakaan kerja di 2004. Seluruh kecelakaan tersebut kecelakaan yang terjadi pada bagian mesin bubut. Hal ini mengindikasikan masih banyak kecelakaan kerja yang terjadi di industri informal. Angka pasti jumlah kecelakaan kerja di industri informal cukup sulit untuk didapatkan karena tidak ada kewajiban dari pemilik usaha untuk melaporkan kecelakaan yang terjadi bahkan tenaga kerja pun tidak merasa harus melaporkan kecelakaan yang terjadi saat dirinya bekerja. 
Kejadian kecelakaan kerja pada 1 industri saja sudah menyebabkan kerugian yang cukup besar pada pemilik usaha. Apabila pemilik usaha memiliki beberapa industri, maka kerugiannya akan semakin besar. Oleh karena itu, aspek keselamatan dan kesehatan kerja (K3) pada industri informal harus digalakkan. Kejadian kecelakaan dan penyakit akibat kerja dapat diminimalisasi dengan hadirnya K3 di tengah-tengah tenaga kerja sektor informal.

Banyaknya jumlah tenaga kerja sektor informal di wilayah kerja Puskesmas Waru mengindikasikan bahwa banyaknya permasalahan K3 yang menjadi tanggung jawabnya. Adanya optimalisasi Pos UKK yang tidak hanya berfokus pada upaya kesehatan kerja melainkan juga upaya keselamatan kerja perlu dilakukan agar kedua sisi ini dapat berjalan beriringan. Tenaga kerja sektor informal terjamin kesehatan dan keselamatannya selama bekerja.

\section{METODE}

Sektor informal masih belum banyak diperhatikan aspek kesehatan dan keselamatan kerjanya oleh negara. Oleh karena itu, Kementerian Kesehatan melalui Puskesmas membuat Pos UKK. Pos UKK perlu dilakukan optimalisasi fungsi yaitu melakukan kegiatan kesehatan kerja sekaligus keselamatan kerja. Puskesmas Waru menginisiasi terbentuknya Pos UKK untuk sector informal dan melakukan pembinaan yang terus menerus hingga mampu menurunkan angka kecelakaan kerja dan penyakit akibat kerja di sektor informal dengan berbagai program yang dapat diusulkan dan diikuti oleh semua tenaga kerja.

Optimalisasi Pos UKK dilakukan dengan beberapa kegiatan berikut:

a. Pemberdayaan petugas Puskesmas di Kabupaten Sidoarjo

b. Brainstorming antara petugas dan sektor informal

c. Pemberdayaan tenaga kerja sektor informal

d. Mapping hazard di tempat kerja

e. Pembuatan program K3 pada sektor informal

Seluruh kegiatan tersebut merupakan rangkaian yang harus dilakukan agar sumber daya manusia yang bertanggung jawab terhadap keberlangsungan Pos UKK yaitu petugas Puskesmas mampu melaksanakan tugasnya sesuai dengan tupoksi. Setelah itu, pihak Puskesmas melakukan kerja sama yang berkesinambungan dengan pihak tenaga kerja sektor informal juga harus dilakukan agar kegiatan K3 dapat dibuat dan menjadi kegiatan prioritas dalam pelaksanaan Pos UKK di Puskesmas Waru. Kegiatan awal perlu dilakukan agar program yang disusun sesuai dengan kebutuhan tenaga kerja. Kegiatan tersebut dapat berupa identifikasi hazard di tempat kerja, mapping hazard tersebut dan menganalisis kejadian kecelakaan kerja dan penyakit akibat kerja.

\section{PEMBAHASAN}

Kegiatan yang dilakukan dalam kegiatan pengabdian masyarakat pada tenaga kerja sektor informal ini meliputi beberapa kegiatan, yaitu:

a. Pemberdayaan petugas Puskesmas di wilayah Kabupaten Sidoarjo Petugas Puskesmas menjadi sasaran dalam kegiatan pertama program pemberdayaan ini karena petugas Puskesmas merupakan petugas utama yang melakukan kegiatan optimalisasi Pos UKK. Petugas Puskesmas merupakan petugas yang memiliki hak dan tanggung jawab terhadap kesehatan dan keselamatan (K3) pada tenaga sektor informal yang ada di wilayah kerjanya. Kegiatan pemberdayaan ini meliputi workshop yang diikuti oleh seluruh petugas Puskesmas di wilayah kerja Dinas Kesehatan Kabupaten Sidoarjo yang memiliki hak dan tanggung jawab terkait kesehatan dan keselamatan kerja. Pelibatan petugas lain yang tidak terkait dengan K3 akan menambahkan pekerjaan petugas tersebut kecuali jika ada penugasan dari pihak Puskesmas. Materi workshop yaitu materi K3 secara umum, yang menjadi dasar pelaksanaan K3 di tempat kerja. Materi tersebut meliputi dasar K3, cara mengidentifikasi hazard, menganalisis risiko, dan meminimalisasinya serta masalah lain yang terkait K3. Materi tersebut merupakan pengetahuan mendasar agar petugas Puskesmas mampu mengidentifikasi permasalahan K3 di lapangan sehingga dapat dilakukan tindakan pencegahan dan penanggulangan. Materi workshop diberikan oleh pemateri dari FKM Unair sesuai dengan keahliannya. Materi yang diberikan tidak hanya berupa teori berupa pengajaran di kelas namun juga berupa simulasi pengaplikasiannya baik di sektor informal maupun di sektor formal sehingga petugas juga mempunyai pengetahuan dasar jika bersinggungan dengan tenaga kerja di sektor formal. Pihak Dinas Kesehatan Kabupaten Sidoarjo juga dilibatkan dalam hal ini agar ada pengawasan langsung dari atasan terkait keberlanjutan workshop yang telah diadakan

b. Brainstorming antara petugas dan sektor informal Kegiatan brainstorming dilakukan untuk mempertemukan petugas Puskesmas dengan kelompok tenaga kerja sektor informal yang ada di wilayah kerja Puskesmas. Hal ini dilakukan karena ada kemungkinan bahwa petugas Puskesmas tidak mengetahui kelompok informal yang menjadi tanggung jawabnya. Kegiatan ini dilakukan agar kedua belah pihak bertemu untuk mengidentifikasi masalah yang terjadi selama ini dan mendapatkan kesepakatan tindak lanjutnya. Hal ini dilakukan agar tenaga kerja mengetahui hal yang harus dilakukannya sehingga memudahkan pihak Puskesmas untuk melakukan kewajibannya pada tenaga kerja sektor informal. Pada kegiatan ini dapat teridentifikasi jenis usaha yang ada di seluruh wilayah 
kerja Puskesmas. Hal ini memudahkan dalam kegiatan berikutnya terkait mapping bidang usaha sector informal agar dapat dibentuk menjadi beberapa Pos UKK. Selain itu, dapat dipilih perwakilan dari setiap bidang usaha agar memudahkan komunikasi dengan pihak Puskesmas.

c. Pemberdayaan tenaga kerja sector informal. Kegiatan pemberdayaan serupa dengan pemberdayaan yang dilakukan pada petugas Puskesmas. Pembedanya adalah pemateri dalam kegiatan ini adalah petugas Puskesmas yang sudah mendapatkan materi workshop pada kegiatan sebelumnya. Materi workshop ini yaitu materi K3 secara umum, yang menjadi dasar pelaksanaan K3 di tempat kerja. Materi tersebut meliputi dasar K3, cara mengidentifikasi hazard, menganalisis risiko, dan meminimalisasinya serta masalah lain yang terkait K3. Materi tersebut merupakan pengetahuan mendasar agar petugas Puskesmas mampu mengidentifikasi permasalahan K3 di lapangan sehingga dapat dilakukan tindakan pencegahan dan penanggulangan. Kegiatan ini dilakukan untuk mempermudah pekerjaan petugas Puskesmas dalam pelaksanaan Pos UKK. Selain itu, dapat terbentuk kader Pos UKK yaitu orang-orang yang sudah mendapatkan materi dari workshop ini sehingga mampu membina masing-masing bidang usahanya. Tenaga kerja merupakan pihak yang sangat dekat dengan hal-hal yang terkait pekerjaannya sehingga lebih mengenal bahaya dan risiko yang ada di tempat kerjanya. Selain itu, antar tenaga kerja juga saling mengenal sehingga dapat saling mengingatkan agar tetap menjaga kesehatan dan keselamatan selama bekerja. Hal ini akan berbeda apabila petugas Puskesmas yang mengingatkan tenaga kerja yang kurang aman karena penerimaan setiap orang berbeda.

d. Mapping hazard di tempat kerja Mapping hazard di tempat kerja dilakukan untuk memudahkan dalam mengelompokkan bagian di ruang kerja dalam kelompok pos UKK tersebut yang mempunyai hazard fisik, kimia, biologi, psikologi, dan ergonomi. Setelah dikelompokkan, maka pengendalian yang dapat dilakukan pun akan semakin mudah.

e. Pembuatan program K3 pada sektor informal Kebanyakan Pos UKK tidak mengerti kegiatan yang harus dilakukannya karena tidak ada data pendukung terkait alasan program atau kegiatan tersebut harus dilakukan. Oleh karena itu, setelah dilakukan berbagai identifikasi di tempat kerja, maka dapat disusun program K3 yang sesuai dengan risiko bahaya yang ada di lingkungan kerja dan di stasiun kerja.

Program K3 yang diusulkan pada anggaran daerah yaitu khusus untuk tenaga kerja sektor informal. Hal ini dikarenakan sektor informal membutuhkan kehadiran negara dalam mengatasi kesehatan dan keselamatan kerjanya. Pembuatan program K3 ini juga dibarengi dengan pembuatan anggaran dana. Tidak ada program yang tidak membutuhkan dana sehingga setiap program yang diperlukan harus disesuaikan dengan keuangan yang sudah ditentukan sebelumnya.

\section{PENUTUP}

\section{Kesimpulan}

Kesimpulan dalam kegiatan ini adalah optimalisasi Pos UKK di Puskesmas Waru dilakukan dengan beberapa kegiatan berikut:

a. Pemberdayaan petugas Puskesmas di Kabupaten Sidoarjo

b. Brainstorming antara petugas dan sektor informal

c. Pemberdayaan tenaga kerja sektor informal

d. Mapping hazard di tempat kerja

e. Pembuatan program K3 pada sektor informal

\section{Saran}

Saran yang kami berikan dalam perbaikan kegiatan pengabdian masyarakat khususnya terkait Pos UKK adalah:

a. Perlu adanya perluasan sasaran karena kegiatan pendampingan dilakukan hanya pada 1 pos UKK di 1 Puskesmas di Kabupaten Sidoarjo

b. Perlu adanya petugas khusus K3 seperti petugas gizi dan sanitarian karena selama ini petugas K3 merupakan fungsi tambahan dari petugas unit lain semisal petugas sanitarian dan perawat dari unit poli umum.

\section{DAFTAR PUSTAKA}

Beacukai. 2017. Bantu Kesulitan Pengusaha Logam Ngingas, Bea Cukai Sidoarjo Kenalkan IKM. Diakses dari http:// www.beacukai.go.id/berita/bantu-kesulitan- pengusahalogam-ngingas-bea-cukai-sidoarjo-kenalkan-ikm-.html pada 20 Februari 2018

Departemen Kesehatan. 2006. Pos Upaya Kesehatan Kerja. Jakarta: Departemen Kesehatan RI.

Puskesmas Waru. 2017. Profil Puskesmas Waru. Diakses dari http://dinkes.sidoarjokab.go.id/profil-puskesmas-waru/ pada 20 Februari 2018

Wignjosoebroto, Sritomo, Arief Rahman, dan Dwi Pramono. 2006. Perancangan Lingkungan Kerja dan Alat Bantu yang Ergonomis untuk Mengurangi Masalah Back Injury dan Tingkat Kecelakaan Kerja pada Departemen Mesin Bubut (Studi Kasus PT Atak Indometal Ngingas Waru-Sidoarjo). Diakses dari http://personal.its.ac.id/ files/pub/2845-m_sritomo-ie- Jurnal\%20TA\%20 Dwi\%20Pramono.pdf pada 20 Februari 2018 